\title{
Visualisation of tissue kallikrein, kininogen and kinin receptors in human skin following trauma and in dermal diseases
}

\author{
Elisabeth Schremmer-Danninger ${ }^{1,2, a, *}$, \\ Strinivasen Naidoo' ${ }^{2}$, Christiane Neuhof ${ }^{3}$, Klaus \\ Valeske $^{3}$, Celia Snyman², Christian Sander ${ }^{4}$, \\ Kanti D. Bhoola ${ }^{2,5}$ and Heinz Neuhof ${ }^{3}$
}

${ }^{1}$ Department of Clinical Chemistry and Clinical Biochemistry, Hospital of Surgery, Ludwig-MaximiliansUniversity Munich, Nussbaumstrasse 20, D-80336 Munich, Germany

${ }^{2}$ Department of Clinical and Experimental Pharmacology, Nelson R. Mandela School of Medicine, University of Natal, Private Bag 7, Congella, Durban 4013, South Africa

${ }^{3}$ Department of Pathophysiology and Experimental Medicine, Justus-Liebig-University Giessen, Klinikstrasse 36, D-35392 Giessen, Germany ${ }^{4}$ Hospital of Dermatology, Ludwig-MaximiliansUniversity Munich, Frauenlobstrasse 9-11, D-80337 Munich, Germany

${ }^{5}$ Asthma and Allergy Research Institute, The University of Australia, Sir Charles Gairdner Hospital, Hospital Avenue, Nedlands WA 6009, Australia

\footnotetext{
* Corresponding author e-mail: elisabeth.schremmer-danninger@med.unimuenchen.de
}

\begin{abstract}
During dermal injury and inflammation the serine proteases kallikreins cleave endogenous, multifunctional substrates (kininogens) to form bradykinin and kallidin. The actions of kinins are mediated by preferential binding to constitutively expressed kinin-B2 receptors or inducible kinin-B1 receptors. A feature of the kinin-B1 receptors is that they show low levels of expression, but are distinctly upregulated following tissue injury and inflammation. Because recent evidence suggested that kininB1 receptors may perform a protective role during inflammation, we investigated the specific occurrence of the kallikrein-kinin components in skin biopsies obtained from normal skin, patients undergoing surgery, basalioma, lichenificated atopic eczema, and psoriasis. The tissue was immunolabelled in order to determine the localisation of tissue pro-kallikrein, kallikrein, kininogen and kinin receptors. The kinin components were visualised in normal, diseased and traumatised skin, except that no labelling was observed for kininogen in normal skin. Of the five types of tissue examined, upregulation of kinin-B1 receptors was observed only in skin biopsies obtained following surgery. In essence, the expression of
\end{abstract}

a Present address: Diabetes Research Institute, Koelner Platz 1 , D-80804 Munich, Germany
kinin-B1 receptors did not appear to be enhanced in the other biopsies. Within the multiple steps of the inflammatory cascade in wound healing, our results suggest an important regulatory role for kinin-B1 receptors during the first phase of inflammation following injury.

Keywords: basalioma (basal cell carcinoma); inflammation; kinin-B1 receptor upregulation; lichenificated atopic eczema; psoriasis.

\section{Introduction}

Kinins are vasoactive peptides that are considered to play a primary role in inflammatory processes. Kinins are formed by the serine proteases kallikreins, which cleave high- and low-molecular-weight kininogens. The biological actions of kinins include smooth muscle contraction, vasodilation, release of inflammatory mediators, plasma extravasation, leukocyte diapedesis, and activation of sensory neurons (Bhoola et al., 1992). Vasodilation, increased vascular permeability and pain perception are distinct inflammatory events produced by injected bradykinin. Kinins act functionally on the circulation as endogenous vasodilator and hypotensive mediators. Of interest also is the co-mitogen property of kinins in the cellular proliferation of keratinocytes (SchremmerDanninger et al., 1995). The effects of kinin peptides are mediated by interaction with pharmacologically distinct receptor types, namely the kinin-B2 and -B1 receptors (Regoli and Barabé, 1980). The kinin-B1 receptor is preferentially activated by the kinins that lack the C-terminal Arg residue: des-Arg10-kallidin and des-Arg9-bradykinin, whereas the kinin-B2 receptor is selective for the parent molecules, namely bradykinin and kallidin. The physiologically prominent, constitutive kinin-B2 receptor has certainly been the subject of intensive investigation in drug development, structure-function activity and functional studies. However, during tissue injury when activated by kinin-B1 agonists, the expression of the kinin-B1 receptor is rapidly upregulated. Such an induced expression is an unusual feature for a $\mathrm{G}$ proteincoupled receptor (Marceau et al., 1998). This is the first study that demonstrates the expression and upregulation of kinin-B1 receptor following trauma in the tissues of human skin. We also demonstrate the localisation of kinin-B2 receptor and the proform and mature protein of tissue kallikrein in normal human skin. An additional aim of our study was to localise components of the kallikreinkinin cascade in selected skin diseases: psoriasis, lichenificated atopic eczema and basalioma.

The results obtained with traumatised skin were compared with those of dermal diseases of the human skin. 


\section{Results}

\section{Rationale for the study}

In particular, children undergoing heart surgery that involves extracorporeal circulation may suffer from massive oedema during the first $24 \mathrm{~h}$ following surgery. The fluid extravasation may represent a kinin-induced effect, since such an action has been shown to occur both in an animal model (Neppl et al., 1991) and in children undergoing cardiopulmonary bypass surgery (Neuhof et al., 2003). The data reported by Neppl et al. (1991) suggest that bradykinin-induced oedema is regulated by the kinin-B2 receptor, and is potentiated by simultaneous stimulation of kinin-B1 receptors. Neuhof et al. (2003) stated that bradykinin appears to be essential for the enhancement of microvascular permeability, although a dominant causal role cannot be claimed. An additional question we wished to clarify was whether the changes in cellular orientation and localisation of the kallikreinkinin proteomes in the traumatised skin differed from those observed in dermal diseases.

Expressed proteins of the kallikrein-kinin cascade were immunolabelled in biopsies of the human skin following injury and in dermal diseases, using specific antibodies. A synopsis is shown in Table 1.

\section{Kinin-B2 receptor}

Specific staining for kinin-B2 receptor proteins was found in keratinocytes of the basal layer of the epidermis, and in fibroblasts of the dermis of normal human skin (Figure $1 E)$. It was also observed in endothelial cells of vessels and in sweat gland cells. Only psoriatic skin biopsies and carcinoma cells of basalioma revealed almost no staining for kinin-B2 receptors. Within the traumatised or diseased skin no change of expression was discernible.

\section{Kinin-B1 receptor}

In all biopsies of diseased skin and of normal skin the kinin-B1 receptor was detected at a very low level, with minimal staining in keratinocytes and fibroblasts (not shown). Sweat gland cells showed higher receptor expression compared to keratinocytes or fibroblasts as visualised here for normal skin (Figure 2A) and lichenificated atopic eczema (Figure 2B). In the surgically traumatised skin biopsies obtained from adult patients who had undergone a heart operation, analysis of labelling of kinin-B1 receptor proteins using quantitative confocal laser scanning microscopy revealed up to 15-fold upregulation of expression within epidermal keratinocytes after the operation. Figure 1A,B shows results for a $67-$ year-old patient.

The mean \pm SEM for all immunofluorescence images analysed for adult biopsies (age $63.5 \pm 8.5 \mathrm{yr}$ ) was slightly lower than for the best example shown: epidermis at the beginning of surgery $(2.8 \pm 2.0) \times 10^{2}$ pixels $/ \mu \mathrm{m}^{2}$, and at the end of surgery $(25.7 \pm 8.2) \times 10^{2}$ pixels $/ \mu \mathrm{m}^{2}$.

In children the upregulation was only up to three-fold, and was observed mainly within the subepidermal layers. Figure 1C,D shows results for the 3.5-year-old child.
The mean \pm SEM for the immunofluorescence images analysed for biopsies from children (ages $3 \mathrm{yr}$ and 3 months $\pm 1 \mathrm{yr}$ and 5 months) for the subepidermal layers was $(11.8 \pm 3.7) \times 10^{2}$ pixels $/ \mu \mathrm{m}^{2}$ at the beginning of surgery, and $(24.0 \pm 5.3) \times 10^{2}$ pixels $/ \mu \mathrm{m}^{2}$ at the end of surgery.

\section{Tissue kallikrein}

In normal skin and in biopsies from lichenificated atopic eczema, basalioma and psoriasis tissue, kallikrein could be visualised by antibody binding in basal keratinocytes and in some keratinocytes of the stratum spinosum of the epidermis, in fibroblasts of the dermis and in sweat gland cells. As an example, tissue kallikrein immunoreactivity within the basal keratinocytes of normal skin is shown in Figure $3 \mathrm{~A}$ and in lichenificated atopic eczema in Figure 3B.

\section{Tissue pro-kallikrein}

In all skin biopsies, positive immunostaining could be shown for basal keratinocytes, fibroblasts and sweat gland cells; less staining was visualised in the keratinocytes of the stratum spinosum. Only minimal staining or no labelling was evident in the fibroblasts of lichenificated atopic eczema. Anti-tissue pro-kallikrein antibody labelling in the cells of sweat glands of normal skin is shown in Figure 2C, lichenificated atopic eczema in Figure 2D, and keratinocytes of the basal, mitotic active epidermal layer of lichenificated atopic eczema in Figure 3C.

\section{Kininogen}

A granular-type of staining deposit with a monoclonal anti-bradykinin antibody, which labels the kinin moiety in the intact kininogen molecule, was evident in the dermis of the basalioma biopsy (Figure 3D), and in the sweat gland ducts of basalioma (Figure 2E) and traumatised skin (Figure 2F). In the epidermis of surgically traumatised skin biopsies, an evenly distributed positive immunoreaction was imaged by FITC immunofluorescence (Figure $3 E)$.

\section{Discussion}

Generalised alteration in permeability with the development of interstitial oedema is a frequent consequence of extracorporeal circulation in paediatric heart surgery and is considered to be related to the circulating levels of kinins. As kinins are known to increase the permeability of blood vessels, the activation of the kallikrein-kinin system and its potential role in the pathogenesis of this intraand postoperative complication was investigated by Neuhof et al. (2003). In patients with a disruption of fluid balance, resulting in oedema, a significantly higher concentration of bradykinin in blood samples was found. The increase in the concentration of bradykinin was paralleled by fluid retention of more than $6 \%$ of body weight during bypass and a 2-day postoperative period. A 10- to 20fold increase in bradykinin during the first 10 min of cardiopulmonary bypass operation was also reported by 
Table 1 Immunolocalisation of components of the kallikrein-kinin system in normal, traumatised and diseased skin.

\begin{tabular}{|c|c|c|c|c|c|c|}
\hline & \multicolumn{2}{|c|}{ Traumatised skin } & \multirow[t]{2}{*}{ Normal skin } & \multirow[t]{2}{*}{ Psoriasis } & \multirow[t]{2}{*}{ Basalioma } & \multirow{2}{*}{$\begin{array}{l}\text { Lichenificated } \\
\text { atopic eczema }\end{array}$} \\
\hline & Child & Adult & & & & \\
\hline $\begin{array}{l}\text { Kinin-B1 } \\
\text { receptor }\end{array}$ & $\begin{array}{l}\text { Subepidermal } \\
\text { layers } \\
\text { upregulated } \\
\text { (Figure } 1 C, D \text { ) }\end{array}$ & $\begin{array}{l}\text { Epidermal } \\
\text { layers } \\
\text { upregulated } \\
\text { (Figure 1A,B) }\end{array}$ & $\begin{array}{l}\text { Epidermal }^{a} \\
\text { keratinocytes } \\
\text { Dermal } \\
\text { fibroblasts } \\
\text { Sweat gland } \\
\text { cells } \\
\text { (Figure 2A) }\end{array}$ & As normal skin & As normal skin & $\begin{array}{l}\text { As normal skin } \\
\text { (Figure 2B) }\end{array}$ \\
\hline $\begin{array}{l}\text { Kinin-B2 } \\
\text { receptor }\end{array}$ & $\begin{array}{l}\text { Basal } \\
\text { keratinocytes } \\
\text { Fibroblasts }\end{array}$ & $\begin{array}{l}\text { Basal } \\
\text { keratinocytes } \\
\text { Fibroblasts }\end{array}$ & $\begin{array}{l}\text { Basal } \\
\text { keratinocytes } \\
\text { (Figure 1E) } \\
\text { Dermal } \\
\text { fibroblasts } \\
\text { Endothelial } \\
\text { cells of } \\
\text { vessels } \\
\text { Sweat gland } \\
\text { cells }\end{array}$ & $\begin{array}{l}\text { As normal skin, } \\
\text { except no } \\
\text { staining of } \\
\text { keratinocytes }\end{array}$ & $\begin{array}{l}\text { As normal skin, } \\
\text { except no } \\
\text { staining of } \\
\text { carcinoma cells }\end{array}$ & As normal skin \\
\hline $\begin{array}{l}\text { Tissue } \\
\text { kallikrein }\end{array}$ & Not evaluated & Not evaluated & $\begin{array}{l}\text { Basal } \\
\text { keratinocytes } \\
\text { (Figure 3A) } \\
\text { Keratinocytes } \\
\text { of stratum } \\
\text { spinosum } \\
\text { Fibroblasts } \\
\text { Sweat gland } \\
\text { cells } \\
\text { (Figure 2C) }\end{array}$ & $\begin{array}{l}\text { Only in } \\
\text { keratinocytes }\end{array}$ & $\begin{array}{l}\text { Keratinocytes } \\
\text { Fibroblasts }\end{array}$ & $\begin{array}{l}\text { Basal } \\
\text { keratinocytes } \\
\text { (Figure 3B) } \\
\text { Fibroblasts }\end{array}$ \\
\hline $\begin{array}{l}\text { Tissue } \\
\text { pro-kallikrein }\end{array}$ & Not evaluated & Not evaluated & $\begin{array}{l}\text { Basal } \\
\text { keratinocytes } \\
\text { Keratinocytes } \\
\text { of stratum } \\
\text { spinosum } \\
\text { Dermal } \\
\text { fibroblasts } \\
\text { Sweat gland } \\
\text { cells }\end{array}$ & As normal skin & As normal skin & $\begin{array}{l}\text { Basal } \\
\text { keratinocytes } \\
\text { (Figure 3C) } \\
\text { No staining of } \\
\text { fibroblasts } \\
\text { Sweat gland } \\
\text { cells } \\
\text { (Figure 2D) }\end{array}$ \\
\hline Kininogen & $\begin{array}{l}\text { No distinct } \\
\text { staining }\end{array}$ & $\begin{array}{l}\text { Infiltrated } \\
\text { plasma in } \\
\text { epidermal } \\
\text { layers } \\
\text { (Figure 3E) } \\
\text { Sweat gland } \\
\text { cells } \\
\text { (Figure 2F) }\end{array}$ & $\begin{array}{l}\text { No distinct } \\
\text { staining }\end{array}$ & $\begin{array}{l}\text { Weak around } \\
\text { fibroblasts }\end{array}$ & $\begin{array}{l}\text { Granular-type } \\
\text { staining } \\
\text { deposited } \\
\text { in the stratum } \\
\text { spinosum of } \\
\text { epidermis and } \\
\text { sweat gland } \\
\text { cells (Figures 3D and 2E) }\end{array}$ & As basalioma \\
\hline
\end{tabular}

aKinin-B1 receptor was found in epidermal keratinocytes and dermal fibroblasts at low levels and in sweat glands at higher levels.

Campbell et al. (2001). The authors measured circulating kinin and kallikrein levels and concluded that activation of the kallikrein-kinin system was indicated.

Since evidence suggests that kinin-B1 receptors may exert a protective role during inflammation, the aim of our study was to investigate the specific occurrence of kininB1 receptors in skin biopsies obtained from patients undergoing heart surgery. The question we asked was whether kinin receptor expression in the skin was altered at the beginning and end of surgery. Image analysis of immunofluorescent labelling in the same adult patient $(n=6)$ showed an up to 15-fold upregulation of the kininB1 receptor in skin biopsies obtained subsequent to heart surgery when compared to the beginning of surgery
(Figure 1A,B). However, in children $(n=3)$ an up to threefold upregulation was evident, mainly in the subepidermal layer (Figure 1C,D), thereby contributing to the disruption of fluid balance observed.

Only in children does a marked degree of fluid retention and oedema in paediatric cardiopulmonary bypass surgery result in delayed chest closure because of massive chest wall oedema, which returns to normal within hours after the end of surgery. Elevated blood concentrations of bradykinin can be observed during extracorporeal circulation (Neuhof et al., 2003). The approximately three-fold upregulation of kinin-B1 receptors (Figure 1C,D) evident within the subepidermal layers of the skin seems to contribute to the disruption of fluid 


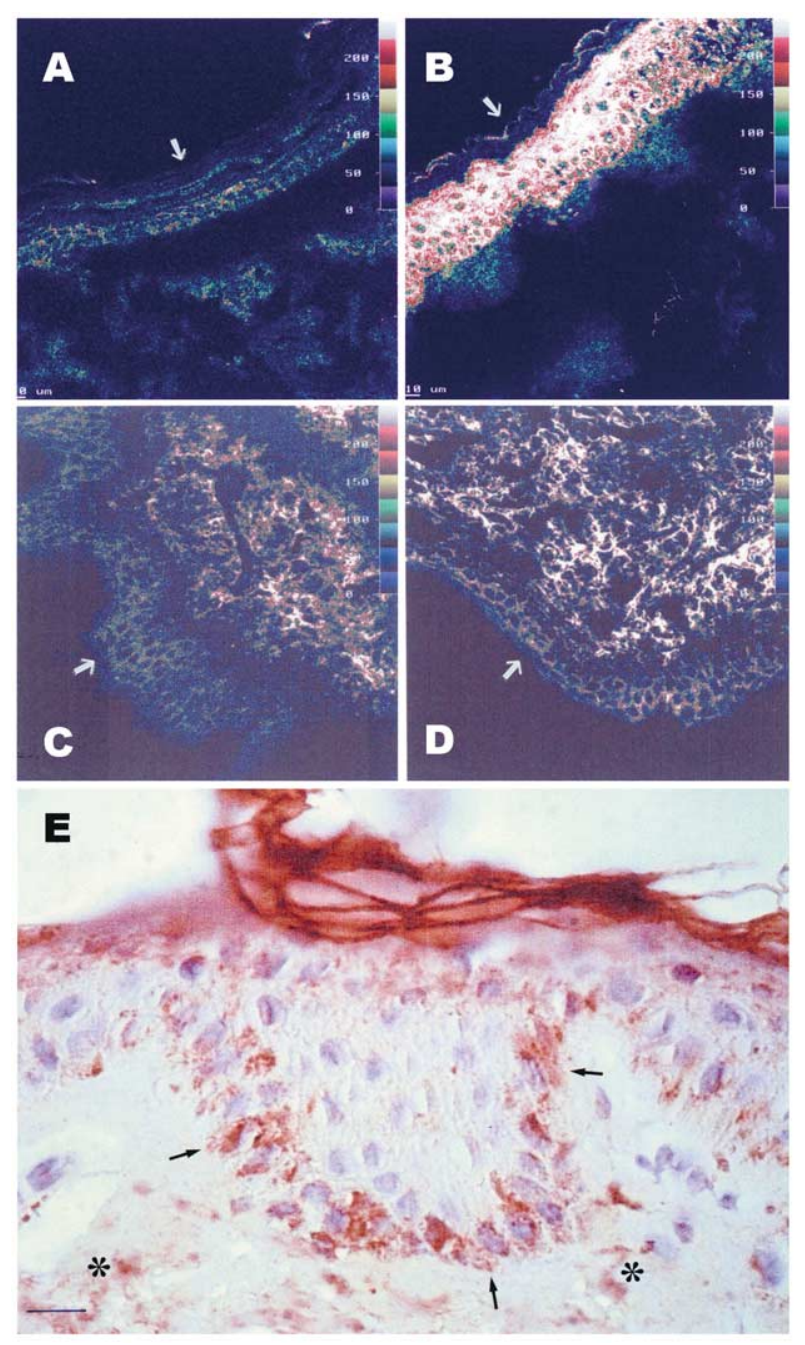

Figure 1 Visualisation of kinin receptors.

(A-D) Kinin-B1-receptor upregulation within epidermis and dermis. Immunovisualisation of kinin-B1 receptor upregulation in $(A, B)$ adult skin and $(C, D)$ in skin obtained from children during heart surgery. Biopsies were obtained at the beginning and at the end of surgery. White arrows point to the outside of the skin with the horny layer. Images from a confocal laser scanning microscope show on the left a skin section cut from a biopsy resected at the beginning of surgery and during extracorporeal circulation. On the right a section cut from a biopsy resected at the end of surgery is shown. The intensity of the colour-coded immunofluorescence, given as greyscale values representing the relative amount of kinin-B1 receptors, is depicted on the colour strip, with red-white as maximum [purple-blue=zero; green-yellow (greyscale phases 89-121)=moderate; red-white (greyscale phases 155-256)=maximum; for precise greyscale values refer to the following]. $(A, B)$ Confocal laser scanning images of adult skin. Colour-coded immunofluorescence intensity within greyscale phases 155-256 for the epidermis: (A) $(2.1 \pm 1.3) \times 10^{2}$ pixels/ $\mu \mathrm{m}^{2}$ (beginning of surgery); and (B) $(31.4 \pm 1.8) \times 10^{2}$ pixels $/ \mu \mathrm{m}^{2}$ (end of surgery). (C,D) Confocal laser scanning images of skin obtained from a child. Colour-coded immunofluorescence intensity within grey scale phases 155-256 for the subepidermal layer: (C) $(10.5 \pm 4.1) \times 10^{2}$ pixels/ $\mu \mathrm{m}^{2}$ (beginning of surgery); and (D) $(28.3 \pm 4.8) \times 10^{2}$ pixels $/ \mu \mathrm{m}^{2}$ (end of surgery). (E) Localisation of kinin-B2 receptors in the epidermis of normal skin. Arrows point to the specifically immunolabelled kinin-B2 receptors, shown as a stained line of basal keratinocytes; above this line are the next layers of the epidermis and below this line of stained keratinocytes is the dermis with specifically stained fibroblasts $\left(^{*}\right)$. Counterstaining was performed with hematoxylin-eosin. Scale bar, $10 \mu \mathrm{m}$. balance observed. Biopsies from three children at the ages of 10 months, 3.5 and $5.5 \mathrm{yr}$ showed almost the same degree of upregulation, of between 2.0- and 2.8fold.

The upregulation of kinin-B1 receptors during the operation within adult epidermis at the site of the operation wound seems to represent a local inflammatory response in wound healing, along with local oedema limited to the site of surgical injury. The upregulation of kinin-B1 receptors ranged between approximately eight- and 15-fold within biopsies of selected adults. Figure $1 \mathrm{~A}, \mathrm{~B}$ shows the best example of upregulation within the epidermis of a 67-year-old adult.

Whereas in children the upregulation of kinin-B1 receptors might represent one factor contributing to marked oedema in cardiopulmonary bypass surgery, the massive upregulation in adults seems to demonstrate the role of kinin-B1 receptors in wound healing.

The striking comparison between children and adults in this study involves not only the extent of upregulation, but also the site of upregulation of kinin-B1 receptors. This upregulation could be visualised within the subepidermal layers in skin biopsies of children, contributing to oedema, whereas in adult skin the epidermis itself was the site of upregulation of kinin-B1 receptors and might represent its involvement in the beginning of wound healing.

Oedema caused by enhanced capillary permeability may have been mediated through kinin-B1 receptors by the in situ formation of kinin-B1 receptor agonist molecules, formed as a result of the simultaneous upregulation of carboxypeptidase $M$. The upregulation of kinin-B1 receptors may be a functional response to antagonise the detrimental effects of the parent kinins, namely bradykinin and kallidin (Neuhof et al., 2003), but possibly also of as yet unknown factors.

From the results of this study, we can assess that in the very first stage after an injury the upregulation of kinin-B1 receptors induces the first step of the kallikreinkinin cascade. These upregulated receptors might play a major role in a physiological protective mechanism that can contribute to wound healing as part of a repair mechanism in adult skin. Concerning the generalised oedema, the upregulation of expression observed in subepidermal skin of children may be part of an over-reaction and/or over-regulation to counteract possible inflammatory reactions.

Rawlingson et al. (2001) reported the rapid involvement of the kinin-B1 receptor in murine skin in microvascular response to burn injury, indicating that these receptors play an essential role in mediating the early rather than the delayed phase of oedema formation, as well as noting neutrophil accumulation in their experiments. This result may also be due to protective reactions and underlines our finding of upregulated kinin-B1 receptors in traumatised skin, but not in biopsies of chronic skin diseases, in which an upregulation of kinin-B1 receptors could not be found. In biopsies of diseased skin (psoriasis, basalioma and lichenificated atopic eczema) no upregulation could be shown. Our finding that the kininB1 receptor protein is expressed in normal skin at quite low levels and that the kinin-B1 receptor gene is consti- 

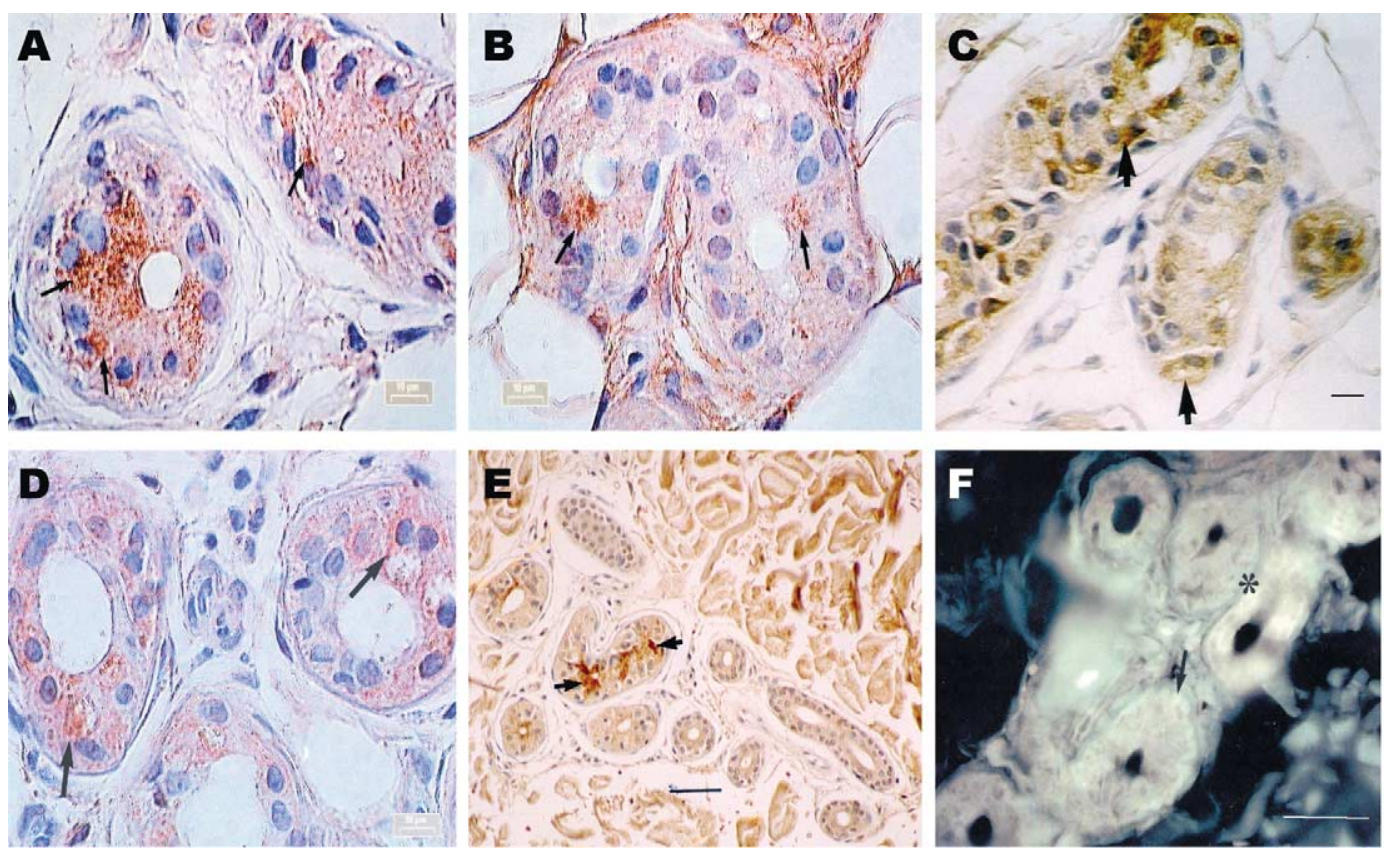

Figure 2 Immunovisualisation of kinin-B1 receptor, tissue pro-kallikrein and kininogen in sweat gland cells of normal skin, lichenificated atopic eczema and of traumatised skin.

Arrows point to the expression of the appropriate visualised protein. (A) Kinin-B1 receptor labelled sites in normal skin; (B) kinin-B1 receptor labelling in lichenificated atopic eczema; (C) tissue pro-kallikrein labelled sites in normal skin; (D) tissue pro-kallikrein labelled sites in lichenificated atopic eczema; (E) kininogen (anti-kinin antibody) staining in a biopsy of basalioma (scale bar, $50 \mu \mathrm{m}$ ); (F) kininogen (anti-kinin antibody) labelled in traumatised skin with fluorescent conjugated antibody (scale bar, $50 \mu \mathrm{m}$ ); the arrow points to a basement membrane; below and to the right of the star, whole cells are stained. For panels (A-E) light microscopy using the peroxidase-antiperoxidase streptavidin-biotin conjugated system was performed, with counterstaining using hematoxylin-eosin. Scale bar length is $10 \mu \mathrm{m}$ unless otherwise stated.

tutively expressed in normal skin (Schremmer-Danninger et al., 1999) agrees with studies by Chai et al. (1996), who also showed kinin-B1 receptor gene expression in various normal human tissues. Our results suggest an important regulatory role for the kinin-B1 receptor within the multiple steps of the cascade necessary for the positive inflammatory processes in wound healing.

For the constitutively expressed kinin-B2 receptor, no differences were observed in the localisation or amount of labelling between the skin biopsies of patients with dermal diseases, except for psoriatic skin, in which no labelling was evident for kinin-B2 receptors in the basal keratinocytes, and for basalioma biopsies, in which carcinoma cells were not labelled by anti-kinin-B2 receptor antibody. This finding may be due to an exceptionally high replication rate, with a late 'thinning out' of kinin-B2 receptors. One view of the enhanced mitogenic activity of the basal keratinocytes in psoriasis may be that kininB2 receptors are functionally active at the onset of a lesion, but not in the chronic state. In healthy skin, kininB2 receptors could be shown in the basal, mitotically active layer of keratinocytes within the epidermis (Figure 1E). The immunolabelled images are in harmony with those previously demonstrated by receptor microautoradiography (Schremmer-Danninger et al., 1995).

In all biopsies investigated in this study, the cellular kinin-B2 receptor (Figure 1E), tissue kallikrein and tissue pro-kallikrein (Figure 3A,B,C) could be visualised, as also demonstrated at the RNA level by Schremmer-Danninger et al. (1999); these components of the kallikrein-kinin system could be demonstrated despite kininogen in normal skin.
Kininogen could be shown in biopsies of basalioma in sweat gland cells (Figure 2E) and in papillary dermis (Figure 3D), as well as in sweat gland cells of traumatised skin (Figure 2F) and in traumatised epidermis (Figure 3E). In the papillary dermis a granular-type of staining deposit was found, whereas within epidermis traumatised by surgery, evenly distributed staining with the fluorescent conjugated antibody could be shown. Considering the importance of leakage of plasma into the epidermis during inflammatory reactions, comprising kininogen, kallidin and bradykinin, this might be the source of ligands for the upregulated kinin-B1 receptors. Whereas in adult patients the leakage of plasma seems to be confined to the epidermal layers, as shown in our study, in children a generalised disturbance of microvascular permeability with marked oedema and effusions takes place as a significant complication of cardiopulmonary bypass (Neuhof et al., 2003). On the other hand, it seems that in chronic disease infiltrating neutrophils represent a source of kininogen (Figure 3D).

A molecular response to infection, tissue injury and proliferation of tumour cells is the secretion of chemotactic molecules that attract neutrophils to sites of inflammation. They interact through the surface anchoring of integrin molecules with endothelial cells, and by the process of diapedesis migrate through capillary gap junctions to gain access into the interstitial tissue space. IL$1 \beta$, TNF- $\alpha$ and bradykinin induced inflammatory-cell neutrophil migration in a rat air-pouch model (Santos et al., 2003). This migration could be markedly reduced by the appropriate inhibitors. Neutrophils bear kininogen (Figueroa et al., 1992, 1999) and neutrophils contain the 

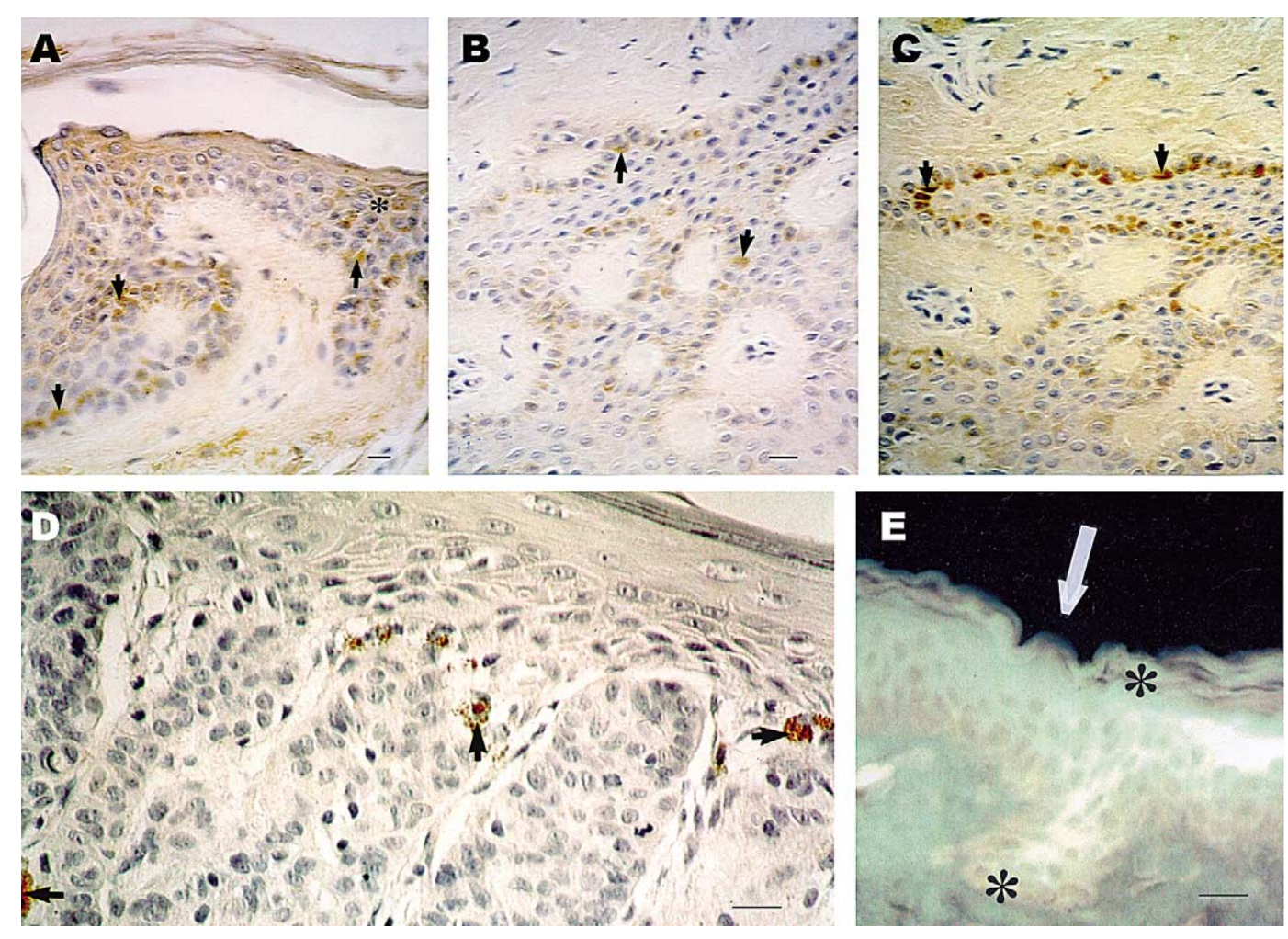

Figure 3 Localisation of (A) tissue kallikrein in normal skin, (B) tissue kallikrein and (C) tissue pro-kallikrein in lichenificated atopic eczema, and (D) kininogen in basalioma and (E) traumatised adult skin.

Examples for normal, traumatised and diseased skin biopsies are depicted. Tissue kallikrein and tissue pro-kallikrein are both localised in basal mitotically active keratinocytes, as visualised by light microscopy using the peroxidase-antiperoxidase streptavidin-biotin conjugated method. The antibody against tissue kallikrein, as well as the antibody against tissue pro-kallikrein, immunoreacted intensely with almost every keratinocyte of the mitotic active layer within the epidermis (see arrows). Anti-tissue kallikrein antibody also reacted with some of the keratinocytes of the stratum spinosum; see staining close to the asterisk in (A). Counterstaining was performed with hematoxylin-eosin. (D) Localisation of kininogen in a basalioma biopsy. Sections of basalioma revealed a granulartype of staining deposits found in the papillary dermis (see arrows). Labelling was performed with the anti-kinin antibody, which detects the kinin moiety in the kininogen molecule. Counterstaining was done with hematoxylin-eosin. (E) Localisation of the kinin moiety in traumatised adult skin. The image shows the highest distribution of staining (FITC immunofluorescence) throughout the epidermal layer between the two asterisks. The arrow points to the outside of the skin. Scale bar, $10 \mu \mathrm{m}$.

complete system for the synthesis and release of bioactive kinins (Bockmann and Paegelow, 2000). In the inflammatory cells of diseased skin, neutrophils attracted by cytokines are a source of kininogen. The granular-type of staining deposit may reflect neutrophil clusters, whereas the evenly distributed staining in traumatised epidermis might show ligands bound to evenly distributed kinin-B1 receptors. The kininogen antibody detects the kinin moiety, including des-Arg-kinins.

Poblete et al. (1991) showed the cellular localisation of immunoreactive tissue kallikrein and kininogen in human sweat glands. In our study, kinin-B1 receptors and tissue pro-kallikrein could be immunovisualised in normal skin sweat gland cells (Figure 2A, C). In traumatised skin, antikininogen antibody reacted with the basement membranes of sweat gland cells (Figure 2F). The full complement of a functionally active kallikrein-kinin system is also present in these human sweat gland cells, which might represent active stimulation of the gland. Whether this stimulation is related to an inflammatory status and its role within these reactions cannot be discussed here. In their paper, Poblete et al. (1991) proposed that an increase in mitotic activity in psoriatic epidermis is a possible effect of kinins.
Taken together, our results suggest an important regulatory role for kinin-B1 receptors during the first stage of inflammation following an injury within the cascade of inflammatory processes in wound healing. The full complement of a functionally active kallikrein-kinin system is observed, when under pathological conditions kininogen arises from non-pre-existing sources.

\section{Materials and methods}

\section{Ethical permission}

Permission to obtain biopsies of human skin was obtained from the appropriate University Ethics Committee (Ludwig-Maximilians-University, Munich and Justus-Liebig-University, Giessen) authorised to review human studies. Written consent was obtained from each patient enrolled in the study. Special care was taken in the case of children, and consent was obtained from the parent or guardian, as required.

\section{Tissue samples and fixation}

Small skin biopsies were obtained from 9 patients at the age of 10 months, 3.5, 5.5, 45, 58, 67, 68, 70 and $73 \mathrm{yr}$, undergoing heart operations, at the beginning and at the end of surgery. 
Histologically normal adult skin was obtained from areas surrounding dermal naeve excised for suspicion of melanoma; biopsies from typical forms of psoriatic skin, lichenificated atopic eczema and basalioma were taken before treatment from two patients with their permission.

Biopsies were immediately fixed in $5 \%$ cold, freshly prepared paraformaldehyde for $24 \mathrm{~h}$, dehydrated in a graded series of ethanol, cleared in xylene and embedded in paraffin. Serial sections $(3 \mu \mathrm{m})$ were cut on a Leitz microtome, mounted onto adhesive-coated (poly-L-lysine, Sigma Chemical Co, St. Louis, USA) glass slides and were used for visualisation of kinin receptors by immunocytochemistry.

\section{Antibodies}

Anti-kinin-B1 receptor antibodies A mixture of antibodies (AS 367-375) directed to various specific sequences of the human kinin-B1 receptor raised in rabbits was provided by $\mathrm{W}$. Müller-Esterl (Johann-Wolfgang-Goethe-University, Frankfurt, Germany) and used at dilutions ranging from 1:100 to 1:1000.

Anti-kinin-B2 receptor antibodies Of the eight polyclonal antibodies fully characterised for specificity, raised against synthetic peptides of the amino-terminal and loop regions encoded by the rat kinin-B2 receptor CDNA and based on the homogeneity between these regions with the human receptor, the four that reacted strongly with human epithelial cells and neutrophils (Haasemann et al., 1994) were chosen to perform the localisation experiments. A combination of antibodies was chosen: LeuHis-Lys-Thr-Asn-Cys-Thr-Val-Ala-Glu for intracellular domain 1 (ID1, LHK, 280) (L-H-K-T-N-C-T-V-A-E for ID1); Asp-Arg-Tyr-LeuAla-Leu-Val-Lys-Thr-Met-Ser-Met-Gly-Arg-Met for intracellular domain 2 (ID2, DRT, 277) (D-R-Y-L-A-L-V-K-T-M-S-M-G-R-M for ID2); and Asp-Thr-Leu-Leu-Arg-Leu-Gly-Val-Leu-Ser-Gly-Cys for the fourth extracellular domain (ED4, DTL, 283) (D-T-L-L-RL-G-V-L-S-G-C for ED4). These antibodies were kindly provided by W. Müller-Esterl (Johann-Wolfgang-Goethe-University, Frankfurt, Germany) and were used at a dilution of 1:500.

Anti-kininogen antibodies A monoclonal mouse anti-bradykinin antibody (donated by M. Webb, Sandoz, UK) was used to immunolabel the kinin moiety in the intact kininogen molecule.

Anti-tissue kallikrein and pro-kallikrein antibodies Both antibodies were prepared as reported previously (Kemme et al., 1999; Naidoo et al., 1999). Specific antiserum for tissue kallikrein was produced in goat using purified recombinant tissue kallikrein. Since this antibody was raised against the mature recombinant enzyme, it detected both the active form and the proform of the enzyme. The IgG fraction was isolated from the antibody to recombinant tissue kallikrein, and used for immunolabelling at a 1:100 dilution. To generate an antibody that discriminated between the active form and proform of tissue pro-kallikrein, the peptide Cys-Ala1-Pro-Pro-Ile-Gln-Ser-Arg7-Ile-Val-Gly10, covering the amino-terminus of tissue pro-kallikrein, was used. An additional Cys-residue was introduced at the amino-terminus of the synthesised peptide to facilitate coupling to the carrier-protein keyhole limpet haemocyanin. This conjugate was used for the production of tissue pro-kallikrein anti-sera in rabbits and the isolated IgG was used at 1:100 dilution for the immunolabelling experiments.

Secondary antibodies The appropriate anti-species antibody IgG, conjugated with either peroxidase or fluorescein, was used as the sandwich antibody.

Immunolabelling controls In order to assess the specificity of the immunolabelling, method controls were prepared in which each primary antibody was replaced by either buffer (PBS) or non-immune serum.

\section{Immunocytochemistry}

Light microscopy peroxidase-antiperoxidase streptavidinbiotin conjugated system Slides with the mounted skin tissue sections were placed on a heating mantle until the wax melted and were then dewaxed in xylene. Tissue was rehydrated through a series of increasingly dilute ethanol solutions and then placed in distilled water as the final rehydrant. Between the $90 \%$ and $70 \%$ ethanol hydration steps, tissue had to be immersed in absolute methanol for $25 \mathrm{~min}$ to quench endogenous peroxidase activity.

Moderate boiling in $0.01 \mathrm{M} \mathrm{Na}$-citrate buffer ( $\mathrm{pH} \mathrm{6.0)}$ for $8 \mathrm{~min}$ at $80^{\circ} \mathrm{C}$ followed for antigen retrieval in a Sharp R-4A52 microwave oven. Then the tissue was allowed to cool to room temperature and placed again in distilled water. Before incubating in $10 \% \mathrm{H}_{2} \mathrm{O}_{2} / 95 \%$ methanol $(\mathrm{v} / \mathrm{v})$ for $20 \mathrm{~min}$ at room temperature to quench endogenous peroxidases a second time, the tissue had to be washed once in $0.01 \mathrm{M} \mathrm{PBS} / 1 \% \mathrm{BSA}$ to reduce nonspecific binding and then twice in $0.01 \mathrm{M}$ PBS. The incubation with the first antibody, diluted in maleic acid/ $10 \%$ milk blocker in PBS (Boehringer, Mannheim, Germany) took place overnight at $4^{\circ} \mathrm{C}$ in a humidified chamber. After two washing steps with $0.01 \mathrm{M}$ PBS, the tissue on the slides was treated with the peroxidase-antiperoxiodase streptavidin-biotin conjugating system (LSAB K0690, DAKO, Hamburg, Germany) for 20 min each, with PBS wash steps in between. The labelled antibody bound to the peroxidase-antiperoxiodase immuno-enzyme complex was visualised by incubating with liquid diaminobenzidine (DAB) precipitant (K3468, DAKO) for up to $4 \mathrm{~min}$ in the dark. Tissues were counterstained with Mayer's haematoxylin. Sections were then dehydrated and mounted in a permanent medium (Entellan; Merck, Darmstadt, Germany) and immunovisualised by conventional light microscopy under a Nikon photomicroscope.

FITC immunofluorescence Wax-embedded tissue sections mounted on silanised slides were processed in the same way as described for the light microscopy peroxidase anti-peroxidase method, except for the $\mathrm{H}_{2} \mathrm{O}_{2}$ step. Before incubation with the first antibody (diluted in $10 \%$ milk blocker) overnight at $4^{\circ} \mathrm{C}$ in a humid chamber, a blocking step of $10 \mathrm{~min}$ at room temperature in $10 \%$ milk blocker was included to reduce non-specific binding.

After incubating with the first antibody, tissue was washed in $0.01 \mathrm{M}$ PBS and incubated for $30 \mathrm{~min}$ at room temperature with anti-species fluorescent conjugate (anti-rabbit IgG FITC conjugate F1262, Sigma). After a washing step with 0.01 M PBS, aqueous mounting with $10 \% \mathrm{PBS} / 90 \%$ glycerol or DAKO fluoromount was carried out. Specific fluorescence emitted by the fluorophore coupled to the secondary antibody could be inspected in a fluorescence microscope (Nikon photomicroscope with fluorescence detection system) and was then visualised, colour-coded and quantified with a confocal laser scanning microscope (Leica TD4, Leica, Solms, Germany).

Analysis of immunofluorescence images The amount of kinin-B1 receptors was computed and colour-coded by image analysis. The mean intensity of immunolabelling was quantified in pixels $\times 10^{2} / \mu \mathrm{m}^{2}$ using the Analysis 2.1 Pro system (Soft-Imaging Software $\mathrm{GmbH}$, Münster, Germany). Confocal images were typically recorded at a density of $225 \times 225$ pixels. The grey scale ranged from 0 to 256, and was divided into 8 equal phases (POLI Look-Up-Table), with each phase having a lower and upper greyscale value threshold. Using the Analysis 2.1 Pro system, the regions of interest for each image were encircled. Each encircled specified tissue area was used to calculate the number of pixels 
falling within each phase in the area analysed. Therefore, the mean intensity of immunolabelling in specific areas was quantified in pixels $/ \mu m^{2}$ (Snyman et al., 1999).

\section{Acknowledgements}

This work was supported by Sonderforschungsbereich 469, Ludwig-Maximilians-University, Munich, Germany, and the International Office Research Centre (KFA), Jülich, Germany. The authors would like to thank Prof. Werner Müller-Esterl, JohannWolfgang-Goethe-University, Frankfurt, Germany for kinin-B1 and $-\mathrm{B} 2$ receptor antibodies.

\section{References}

Bockmann, S., and Paegelow, I. (2000). Kinins and kinin receptors: importance for the activation of leukocytes. J. Leukoc. Biol. 68, 587-592

Bhoola, K.D., Figueroa, C.D., and Worthy, K. (1992). Bioregulation of kinins: kallikreins, kininogens and kininase. Pharmacol. Rev. 44, 1-80.

Campbell, C.J., Dixon, B., Kladis, A., Kemme, M., and Santamaria, J.D. (2001). Activation of the kallikrein-kinin system by cardiopulmonary bypass in humans. Am. J. Physiol. Regul. Integr. Comp. Physiol. 28, R1059-1070.

Chai, K.X., Ni, A., Wang, D., Ward, D.C., Chao, J., and Chao, L. (1996). Genomic DNA sequence, expression, and chromosomal localisation of the human B1 bradykinin receptor gene BDKRB1. Genomics 31, 51-57.

Figueroa, C.D., Henderson, L.M., Kaufmann, J., de la Cadena, R.A., Colman, R.W., Müller-Esterl, W., and Bhoola, K.D. (1992). Immunovisualisation of high (HK) and low (LK) molecular weight kininogens on isolated human neutrophils. Blood $79,754-759$

Figueroa, C.D., Stuardo, M., Gonzales, C.B., Nualart, F., Corthorn, J., and Bhoola, K.D. (1999). Hydrolysis of kininogens by degranulated human neutrophils and analysis of bradykinin as chemotactic factor for cells isolated from peripheral blood. Immunopharmacology 43, 211-217.

Haasemann, M., Figueroa, C.D., Henderson, L., Grigoriev, S., Abd Alla, S., Gonzalez, C.D., Dunia, I., Hoebeke, K., Jarnagin, K., Cartaud, J., et al. (1994). Distribution of bradykinin B2 receptors in target cells of kinin action. Visualisation of the receptor protein in A431 cells, neutrophils and kidney section. Braz. J. Med. Biol. Res. 27, 1739-1756.
Kemme, M., Podlich, D., Raidoo, D.M., Snyman, C., Naidoo, S., and Bhoola, K.D. (1999). Identification of immunoreactive tissue prokallikrein on the surface membrane of human neutrophils. Biol. Chem. 380, 1321-1328.

Marceau, F., Hess, J.F., and Bachvarov, D.R. (1998). The B1 receptors for kinins. Pharmacol. Rev. 50, 357-386.

Naidoo, Y., Snyman, C.J,. Raidoo, K.M., Bhoola, K.D., Kemme, M., and Müller-Esterl, W. (1999). Cellular visualisation of tissue pro-kallikrein in human neutrophils and myelocytes. $\mathrm{Br}$. J. Haematol. 105, 599-612.

Neppl, H., Neuhof, H., Afflerbach, F., Llach Puig Neppl, J. and Berghofer, A. (1991). Bradykinin-induced oedema formation proceeds from B2 receptor stimulation and is potentiated by concomitantly released prostaglandins. Acta Physiol. Scand. 142, 141-147.

Neuhof, C., Walter, O., Dapper, F., Bauer, J., Zickmann, B., Fink, E., Tillmanns, H., and Neuhof, H. (2003). Bradykinin and histamine generation with generalized enhancement of microvascular permeability in neonates, infants, and children undergoing cardiopulmonary bypass surgery. Pediatr. Crit. Care Med. 4, 299-304.

Poblete, M.T., Reynolds, N.J., Figueroa, C.D., Burton, J.L., Müller-Esterl, W. and Bhoola, K.D. (1991). Tissue kallikrein and kininogen in human sweat glands and psoriatic skin. Br. J. Dermatol. 124, 236-241.

Rawlingson, A., Gerard, N.P., and Brain, S.D. (2001). Interactive contribution of NK(1) and kinin receptors to the acute inflammatory oedema observed in response to noxious heat stimulation: studies in $\mathrm{NK}(1)$ receptor knockout mice. Br. J. Pharmacol. 134, 1805-1813.

Regoli, D., and Barabé, J. (1980). Pharmacology of bradykinin and related kinins. Pharmacol. Rev. 32, 1-46.

Santos, D.R., Calixto, J.B. and Souza, G.E. (2003). Effect of a kinin B2 receptor antagonist on LPS- and cytokine-induced neutrophil migration in rats. Br. J. Pharmacol. 139, 271-278.

Schremmer-Danninger, E., Heinz-Erian, P., Toepfer-Petersen, E., and Roscher, A.A. (1995). Autoradiographic localisation and characterisation of bradykinin receptors in human skin. Eur. J. Pharmacol. 283, 207-216.

Schremmer-Danninger, E., Hermann, A., Fink, E., Fritz, H., and Roscher, A.A. (1999). Identification and occurrence of $\mathrm{m}$ RNAs for components of the kallikrein-kinin system in human skin and in skin diseases. Immunopharmacology 43 , 287-291.

Snyman, C.J., Raidoo, D.M., and Bhoola, K.D. (1999). Localisation of proteases and peptide receptors by confocal microscopy. Methods Enzymol. 307, 368-394.

Received July 23, 2004; accepted September 10, 2004 